\title{
Are All Engineering Students Capable of Recognizing Ethical and Profes- sional Issues? An Assessment Approach to Engineering Ethics
}

\section{Mrs. Isabel Hilliger, Pontificia Universidad Católica de Chile}

Isabel Hilliger is the Associate Director for Assessment and Evaluation in the School of Engineering at Pontificia Universidad Católica de Chile. She creates qualitative and quantitative instruments for measuring engineering student outcomes. She conducts research on engineering assessment and its effect on the continuous improvement process of practices in engineering education. Her primary research interest is evaluating policy efforts that acknowledge learner diversity, and understand their effects in students performance. Isabel received her professional degree in biological engineering at the Pontificia Universidad Católica de Chile and her MA in policy, organizations and leadership studies at Stanford Graduate School of Education.

\section{Mr. Andrés Strello, Pontificia Universidad Católica de Chile}

Andrés Strello is Licenciated in Sociology, currently Master in Sociology graduate student in the Pontifical Catholic University of Chile.

\section{Miss Francisca Castro, Pontificia Universidad Católica de Chile}

Francisca Castro is a master' student in the Institute of Sociology at Pontificia Universidad Católica de Chile. Her research includes social inequalities and gender. She received her professional degree in Political Science and Sociology at Pontificia Universidad Católica de Chile.

\section{Dr. Mar Pérez-Sanagustín, Pontificia Universidad Católica de Chile}

Mar Pérez-Sanagustín is a researcher and Assistant Professor at the Computer Science Department of the Pontificia Universidad Católica de Chile and the Director of the Engineering Education Division at the same university. Her research interests are technology-enhanced learning, engineering education, MOOCs and b-learning. 
Are all engineering students capable of recognizing ethical and professional issues? An assessment approach to engineering ethics. 


\begin{abstract}
Engineering schools offer ethical training along with the transfer of technical knowledge and the development of other professional skills. The primary objective of this training is to prepare engineering graduates to face diverse ethical issues in the workplace. Thus, exhaustive information is needed to assess whether students are able to recognize potential conflicts that may arise during practice. Despite its importance, there are few studies about the assessment of this ability. This study presents a sequential mixed methodology to assess rigorously the ethics teaching and learning experience in a selective engineering school in Chile. First, we interviewed school authorities, faculty and undergraduate students about their perceptions of the school's approaches to teach ethics. Second, we designed a quantitative instrument to measure students' ability to recognize ethical and professional issues, to accept personal responsibility, to be aware of ethical codes, and to obtain learning benefits from different ethics training activities. Significant differences were found in individual ethical reasoning to identify issues by gender and socioeconomic status. Implications regarding improvement actions in the research site were discussed. Additionally, considerations for adopting the assessment approach by other institutions were also presented.
\end{abstract}

\title{
Introduction
}

Engineering solutions have a long-term impact on society, as the work of engineers can affect public health, safety, business practices and even politics ${ }^{1}$. For this reason, schools of engineering not only develop technical skills in their students, but also prepare them to work collaboratively with others, to communicate effectively, and to assume professional and ethical responsibilities in engineering situations ${ }^{2}$.

Since the Accreditation Board for Engineering and Technology (ABET) adopted the Engineering Criteria 2000 (EC2000) in 1996, engineering programs have been required to assess students' understanding of professional and ethical responsibility ${ }^{3}$. Recently, ABET revised criterion 3, reframing this professional skill as the 'ability to recognize ethical and professional responsibilities in engineering situations and make informed judgements, which must consider the impact of engineering solutions in global, economic, environmental, and societal contexts' 4 . Although ABET's proposed revision has already raised some critical opinions among researchers, academics sustain that the ethical competency is both assessable and relevant ${ }^{5}$.

Few studies have explored the assessment of the effectiveness of engineering teaching to develop students' ethical reasoning. On the one hand, researchers have proposed ethical reasoning tests and case study analysis for measuring students' abilities to recognize an ethical issue $^{6,7}$. On the other hand, questionnaires have been applied for assessing ethical teaching activities from the students' perspective. Institutions would benefit from assessment methodologies that integrate these two approaches, aligning constructively the appraisal of teaching activities with students' understanding of professional ethics.

The research questions that motivated this study are:

RQ1: What are the aspects to assess the effectiveness of ethics education in an engineering school? 
RQ2: Are all engineering students capable of identifying ethical and professional issues that arise in engineering education and practice?

This study addresses several important issues in the assessment of engineering ethics teaching. First, it explores the perspectives of school authorities, faculty, and students of the same research site about ethics teaching and its learning benefits. Second, it proposes an instrument to assess individual ethical reasoning. By individual ethical reasoning, we refer to the ability to recognize ethical and professional issues regarding personal standards and professional codes. A holistic assessment approach was adopted to contribute to the existing knowledge of engineering ethics.

The article is structured as follows. First, we present a theoretical framework about the assessment of engineering ethics. Second, we describe the sequential mixed methodology that we used to explore the ethics teaching and learning experience of a selective engineering school in Chile. Then we present the findings from the qualitative information collected through interviewing school authorities, faculty, and undergraduate students about ethics teaching and learning activities within the institution. We also show the results of a quantitative questionnaire that was given to a stratified sample of undergraduate students. Finally, implications of our work are discussed.

\section{Theoretical framework}

Ethical dilemmas that are part of the engineering workplace have no absolute solution, same as any dilemma in other contexts ${ }^{1}$. Future engineers may find themselves in a difficult situation where they need to make decisions considering multiple restrictions. An effective decision-making process needs to ensure the quality of their work for the safety of the population. Consequently, engineering ethical training should be aimed to develop students' ethical reasoning rather than overwhelming them to discover a correct answer and execute it unhesitatingly ${ }^{15}$.To prepare future engineers face ethical issues in the workplace, students need to identify and discuss dilemmas related to safety, environmental sustainability, cost and time pressures, among other issues ${ }^{9}$. Therefore, future engineers must be trained to deal with diverse conflictive scenarios.

There are different teaching approaches to develop the ability to identify ethical dilemmas among engineering students, so they become capable of recognizing ethical and professional responsibilities. A first approach consists in offering ethics courses, either provided by the engineering school itself or by a philosophy department ${ }^{9,10}$. The second approach is represented by brief discussions on ethics and professional responsibility in specific courses. A third method implies the development of modules or talks on engineering ethics and professional responsibility, which typically consist of two or three class sessions ${ }^{9}$. Finally, ethics teaching could be adopted as a transversal approach across the engineering curriculum ${ }^{11}$.

Recent research has documented a number of difficulties in integrating ethical training into engineering curriculum. Nowadays, one of the limitations is related to time constraints. There is no time available in engineering curriculums to include ethics and other activities for developing a broader set of skills, such as entrepreneurship, and research based learning ${ }^{16}$. This 
barrier is not only related to the time allocation within a curriculum period, but also with the challenge of ensuring time for continuous assessment and effective feedback provision. Studies also allude to other constraints such as budgeting, potentially conflicting interests within an institution, and roles' complexity ${ }^{16}$. Concerning these barriers, collaborative efforts are needed to integrate ethics to engineering training, particularly among engineering faculty. They can provide further guidance on how ethics education should be delivered, and when and where to integrate ethics instruction into the core engineering courses ${ }^{17}$.

Concerning engineering ethical education, it is also necessary to revise the ethical standards at the professional level are. Around methodologies of teaching ethical codes, there are different teaching approaches discussed in literature. The most relevant is case-based teaching to encourage students to apply ethical codes in courses of their later years ${ }^{9}$. Other authors suggest that ethical teaching can be linked with team methodologies around project design ${ }^{12}$. This collective approach facilitates the assessment of the understanding of important norms and decision making processes, which could be a difficult aspect to assess individually.

In spite of the differences that may exist among disciplines or countries, all engineering ethical codes share certain core values. These values are: contributing to the human well-being, the responsibility of the profession towards the population, public safety, environmental sustainability, and broad public mission ${ }^{9,10}$. Other overarching cornerstones of codes are public safety, environmental sustainability, and a broad public mission ${ }^{9}$. Therefore, ethical teaching and learning activities are expected to generate certain results, such as an increase in ethical sensitivity, greater knowledge of relevant standards of conduct, and improved ethical judgment to act ethically when desired or required ${ }^{11,13}$.

There are few studies on the assessment of ethics teaching and learning. Some academics have asserted that values and ethical reasoning are not commensurable, quantifiable, or capable of being subject to empirical and objective analysis ${ }^{7}$. However, there are researchers that still sustain that ethical teaching and learning is assessable ${ }^{5}$. According to Self and Ellison (1998), one way to verify ethical learning is the Defining Issues Test (DIT) ${ }^{7}$. This test is a quantitative instrument that has been widely used to evaluate moral development. Another form of evaluation that differs from quantitative questionnaires is the one suggested by Shuman et al. (2004). He provided a guideline for evaluating the responses to analysis of a case study ${ }^{6}$. This approach has prevailed along with reflective essays, besides other emerging methods used to accountability on ethical understanding and multiperspective thinking 5 .

From an institutional perspective, Finelli et al. (2012) presented the results of a study of students' ethics regarding their exposure to learning opportunities during an engineering program, regarding core courses and elective courses, as well as extracurricular activities ${ }^{8}$. This study determined that the exposition occurs mainly in the first years of the program without having much possibility of discussing the real implications of their ethical understanding in their future work as engineers. Another assessment attempt was made by May and Luth (2013) ${ }^{14}$. By a quasi-experimental design, they sought to determine the impact of ethics teaching on several dimensions: the student's perspective, moral efficiency, moral courage and moral sense, as well as knowledge about responsible behavior ${ }^{15}$. This study showed a positive effect for moral meaningfulness in those students who took a class with an ethics module. 
More research needs to propose holistic assessments of engineering ethics education. There are different aspects of the ethical competency that constitute observable behaviors, such as individual ethical reasoning, the understanding of professional codes, and the ability to recognize individual or shared responsibilities. Additionally, there are different teaching approaches that affect ethical understanding, such as ethics courses, talks or modules about ethical issues, or case-based teaching. A holistic assessment method of ethics teaching would not only be useful for measuring students' achievement in different areas of ethics mastery, but it would also contribute to an improvement of teaching methodologies with valuable information.

\section{Methods}

Objectives of the Study

The primary objective of this study is to contribute to the existing body of knowledge about assessment of engineering ethical training. The specific objectives of this study are the following:

- To explore the perspectives of school authorities, faculty and students about the teaching and learning experiences on engineering ethics in a specific school of engineering.

- To develop a quantitative instrument based on the perspectives of authorities, faculty, and students to assess holistically the engineering ethics education in a specific school of engineering.

- To measure students' ability to recognize ethical and professional issues, to accept personal responsibility and to be aware of ethical codes.

- To compare results of these measurements among different students' subgroups.

\section{$\underline{\text { Research site }}$}

The research site consisted in a private and confessional institution of higher education in Chile. Its engineering school is part of a multi-school campus. Despite the full academic and administrative autonomy conferred by law in the 1930s, this institution claims a public role. Yet, it has a close relationship with the private sector and a strong commitment to entrepreneurship and innovation. It attracts students with high scores according to the Chilean national admission system for higher education, who in most cases were educated in private fee-paying schools (see Table 1).

Table 1: Overall demographic trends of students admitted at the research site.

\begin{tabular}{llllll}
\hline & 2011 & 2012 & 2013 & 2014 & 2015 \\
\hline Total number of students admitted (n) & $(584)$ & $(603)$ & $(762)$ & $(783)$ & $(759)$ \\
Female students & $20 \%$ & $20 \%$ & $21 \%$ & $27 \%$ & $24 \%$ \\
Graduates from private fee-paying schools & $77 \%$ & $77 \%$ & $74 \%$ & $71 \%$ & $72 \%$ \\
Graduates from private subsidized schools & $12 \%$ & $14 \%$ & $18 \%$ & $21 \%$ & $20 \%$ \\
Graduates from municipal schools & $11 \%$ & $9 \%$ & $8 \%$ & $8 \%$ & $8 \%$ \\
\hline
\end{tabular}




\section{Participants, Sampling and Data Gathering Techniques}

In this study, we adopted a sequential exploratory design of an initial qualitative phase followed by a quantitative phase. The aim of employing this research design was to create an instrument to assess holistically different aspects of engineering ethics teaching in a prestigious engineering school in Chile (see Figure 1).

Figure 1: A Sequential Exploratory Design to Assess Different Aspects of Engineering Ethics Teaching and Learning

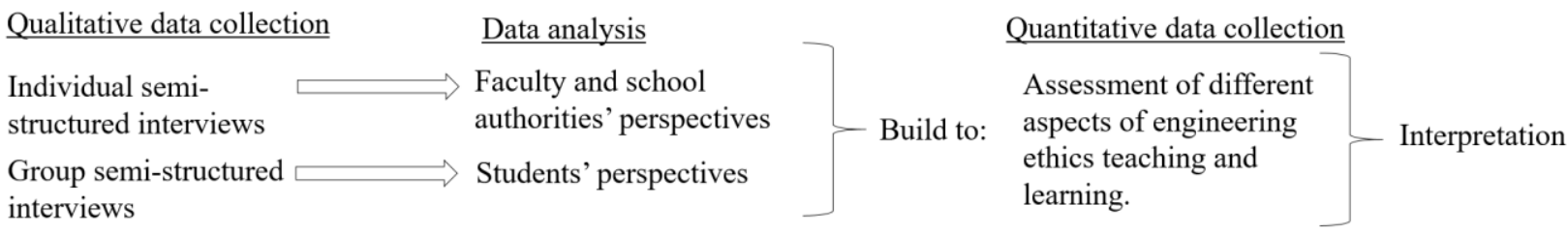

Table 2 describes the number of participants per qualitative data gathering technique. Concerning students, the population of interest were students close to the moment of graduates, besides freshmen that have recently taken a first-year ethics course. The method used for inviting them to participate in group, semi-structured interviews was stratified random sampling. We used this sampling method to ensure the participation of minorities, such as women and students that did not graduate from private-fee paying schools (see Table 1). There was a higher number of participants in the group interviews with future graduates. Thus, two interviews were held simultaneously with 15 students each. Concerning freshmen, there was a low number of participants so we cannot assure that information was saturated in that group semi-structured interview. The method used for inviting associate deans and faculty members was convenience sampling. Two of eight associate deans and eight of 150 faculty members participated in individual interviews.

Table 2: Number of Participants per Data Gathering Technique during the Qualitative Phase of the Study

\begin{tabular}{lr}
\hline Data Gathering Technique & Number of Participants \\
\hline Group interview with freshmen & 3 \\
Group interview with students close to graduation & 30 \\
Individual interviews with school authorities and faculty & 10 \\
\hline
\end{tabular}

We established certain dimensions of analysis to define questions for interviewing school authorities and faculty (see Table 3 and 4 respectively). These dimensions are coherent and consistent with the previous theoretical framework.

Table 3: Dimensions to Define Questions for Semi-structured Interviews with School Authorities

\begin{tabular}{|l|l|l|}
\hline Dimensions & Sub-dimensions & Justification \\
\hline $\begin{array}{l}\text { School approach towards } \\
\text { ethical teaching and learning }\end{array}$ & $\begin{array}{l}\text { Guiding principles to teach ethics in } \\
\text { engineering }\end{array}$ & $\begin{array}{l}\text { These sub dimensions intended to } \\
\text { create a common ground between }\end{array}$ \\
\hline
\end{tabular}




\begin{tabular}{|c|c|c|}
\hline Dimensions & Sub-dimensions & Justification \\
\hline & Main goals of ethics teaching in the school & \multirow{2}{*}{$\begin{array}{l}\text { the interviewee and the research. } \\
\text { Besides, they explore curricular and } \\
\text { extracurricular activities towards } \\
\text { ethics teaching. }\end{array}$} \\
\hline & $\begin{array}{l}\text { Existing ethical teaching activities within } \\
\text { the school }\end{array}$ & \\
\hline \multirow{3}{*}{$\begin{array}{l}\text { School authorities } \\
\text { perspective on students' } \\
\text { attainment of ethical } \\
\text { understanding at an } \\
\text { individual and professional } \\
\text { level }\end{array}$} & Ethical behavior in the school context & \multirow{3}{*}{$\begin{array}{l}\text { These sub-dimensions were used in } \\
\text { order to integrate authorities' } \\
\text { perceptions of the effectiveness of } \\
\text { the current approaches towards } \\
\text { ethics teaching. }\end{array}$} \\
\hline & $\begin{array}{l}\text { Aspects that affect students' ethical } \\
\text { understanding }\end{array}$ & \\
\hline & $\begin{array}{l}\text { Alumni abilities to assume ethical } \\
\text { responsibilities }\end{array}$ & \\
\hline
\end{tabular}

Table 4: Dimensions to Define Questions for Semi-structured Interviews with Faculty

\begin{tabular}{|c|c|c|}
\hline Dimensions & Sub-dimensions & Justification \\
\hline \multirow{3}{*}{$\begin{array}{l}\text { Participation in ethical } \\
\text { training activities }\end{array}$} & $\begin{array}{l}\text { Description of the ethical training activity } \\
\text { that the faculty leads }\end{array}$ & \multirow{3}{*}{$\begin{array}{l}\text { These sub-dimensions were used to } \\
\text { explore the role assumed by the } \\
\text { interviewed faculty in the school's } \\
\text { approach towards ethics teaching. }\end{array}$} \\
\hline & $\begin{array}{l}\text { Learning outcomes expected of the ethical } \\
\text { training activity }\end{array}$ & \\
\hline & Challenges of ethical training activity & \\
\hline \multirow[t]{2}{*}{$\begin{array}{l}\text { Assessment of ethical } \\
\text { learning }\end{array}$} & $\begin{array}{l}\text { Description of classroom assessment } \\
\text { techniques used for measuring ethical } \\
\text { learning }\end{array}$ & \multirow{2}{*}{$\begin{array}{l}\text { These sub-dimensions intended to } \\
\text { reveal faculty's perceptions of the } \\
\text { effectiveness of their approaches to } \\
\text { teach ethics, besides their } \\
\text { responsibility concerning students' } \\
\text { outcome attainment. }\end{array}$} \\
\hline & $\begin{array}{l}\text { Description of actions informed by ethical } \\
\text { learning results }\end{array}$ & \\
\hline \multirow{2}{*}{$\begin{array}{l}\text { Faculty perceptions on } \\
\text { students' attitudes towards } \\
\text { ethical training }\end{array}$} & $\begin{array}{l}\text { Description of students' motivation during } \\
\text { ethical training }\end{array}$ & \multirow{2}{*}{$\begin{array}{l}\text { These sub-dimensions explored } \\
\text { students' attitudes towards ethical } \\
\text { training from the faculty } \\
\text { perspective. }\end{array}$} \\
\hline & $\begin{array}{l}\text { Importance given by students to ethical } \\
\text { learning concerning their future in the } \\
\text { workplace }\end{array}$ & \\
\hline
\end{tabular}

Regarding group, semi-structured interviews with two students, we interviewed freshmen separately from students close to graduation. As in the individual interviews with associate deans and faculty, we established certain dimensions of analysis to define the questions (see Table 5 and 6 respectively). These dimensions are also coherent and consistent with the previous theoretical framework.

Table 5: Dimensions of Questions for Group, Semi-structured Interviews with Freshmen

\begin{tabular}{|c|c|c|}
\hline Dimensions & Sub-dimensions & Justification \\
\hline \multirow{3}{*}{$\begin{array}{l}\text { Students' attitudes towards } \\
\text { ethical training }\end{array}$} & $\begin{array}{l}\text { Importance of ethical training in } \\
\text { engineering education }\end{array}$ & \multirow{3}{*}{$\begin{array}{l}\text { These sub-dimensions explored } \\
\text { students' attitudes towards ethical } \\
\text { training. }\end{array}$} \\
\hline & Main goal of compulsory ethics course & \\
\hline & Role of engineers in social issues & \\
\hline \multirow{3}{*}{$\begin{array}{l}\text { Assessment of ethical } \\
\text { teaching and learning } \\
\text { activities }\end{array}$} & $\begin{array}{l}\text { Ethical content addressed in compulsory } \\
\text { ethics course }\end{array}$ & \multirow{3}{*}{$\begin{array}{l}\text { These sub dimensions intended to } \\
\text { reveal students' perceptions of the } \\
\text { effectiveness of the approaches } \\
\text { adopted to teach ethics, particularly } \\
\text { regarding the compulsory ethics } \\
\text { course for freshmen. }\end{array}$} \\
\hline & $\begin{array}{l}\text { Learning benefits of compulsory ethics } \\
\text { course }\end{array}$ & \\
\hline & Students' motivation during ethics course & \\
\hline
\end{tabular}


Table 6: Dimensions of Questions for Group, Semi-structured Interviews with Students Close to Graduation

\begin{tabular}{|c|c|c|}
\hline Dimensions & Sub-dimensions & Justification \\
\hline \multirow{3}{*}{$\begin{array}{l}\text { Students' attitudes towards } \\
\text { ethical training }\end{array}$} & $\begin{array}{l}\text { Importance of ethical training in } \\
\text { engineering education }\end{array}$ & \multirow{3}{*}{$\begin{array}{l}\text { These sub-dimensions explored } \\
\text { students' attitudes towards ethical } \\
\text { training in order to assess the } \\
\text { effectiveness of the current } \\
\text { approach of ethical training. }\end{array}$} \\
\hline & $\begin{array}{l}\text { Exposure to ethical dilemmas in } \\
\text { engineering }\end{array}$ & \\
\hline & $\begin{array}{l}\text { Importance of ethical training in } \\
\text { engineering workplace }\end{array}$ & \\
\hline \multirow{3}{*}{$\begin{array}{l}\text { Assessment of ethical } \\
\text { teaching and learning } \\
\text { activities }\end{array}$} & $\begin{array}{l}\text { Effective ethical training activities } \\
\text { experienced during the engineering studies }\end{array}$ & \multirow{3}{*}{$\begin{array}{l}\text { These sub-dimensions intended to } \\
\text { reveal students' perceptions of the } \\
\text { effectiveness of faculty's } \\
\text { approaches to teach ethics, besides } \\
\text { their awareness of the ethical } \\
\text { training for their future. }\end{array}$} \\
\hline & $\begin{array}{l}\text { Description of actions informed by ethical } \\
\text { learning results }\end{array}$ & \\
\hline & $\begin{array}{l}\text { Importance given to ethical learning } \\
\text { concerning their future }\end{array}$ & \\
\hline
\end{tabular}

Consequently, a quantitative instrument was designed based on the findings of the qualitative data analysis. The purpose of this instrument is to measure students' ability to recognize ethical and professional issues, to accept personal responsibility and to be aware of ethical codes. Considering students admitted between 2011 and 2015, the research site has an overall enrollment of 4,015 students. Thus, the quantitative instrument was applied online in a random population of half of the enrollment (2,090 students). We carried out a one-stage stratified sampling to define this population. The strata were formed based on gender, type of high school of graduation, and admission cohort (see Table 7). We over-represented female students, freshmen and students that graduated from municipal and private-subsidized schools because they characterize minorities in the overall enrollment (see Table 1). The students were invited to participate voluntarily by email (an informed consent form was included in the first page of the questionnaire). The questionnaire was both anonymous and confidential.

Table 7: Descriptive Statistics of the Sample for Quantitative Data Collection

\begin{tabular}{rrrr}
\hline & & Sample & School enrollment \\
\hline Gender & Female students & $31.5 \%$ & $23.5 \%$ \\
& Male Students & $68.5 \%$ & $76.5 \%$ \\
\hline Students' admission & 2011 & $8.2 \%$ & $13.1 \%$ \\
cohort & 2012 & $12.4 \%$ & $15.0 \%$ \\
& 2013 & $17.5 \%$ & $18.1 \%$ \\
& 2014 & $15.3 \%$ & $18.9 \%$
\end{tabular}




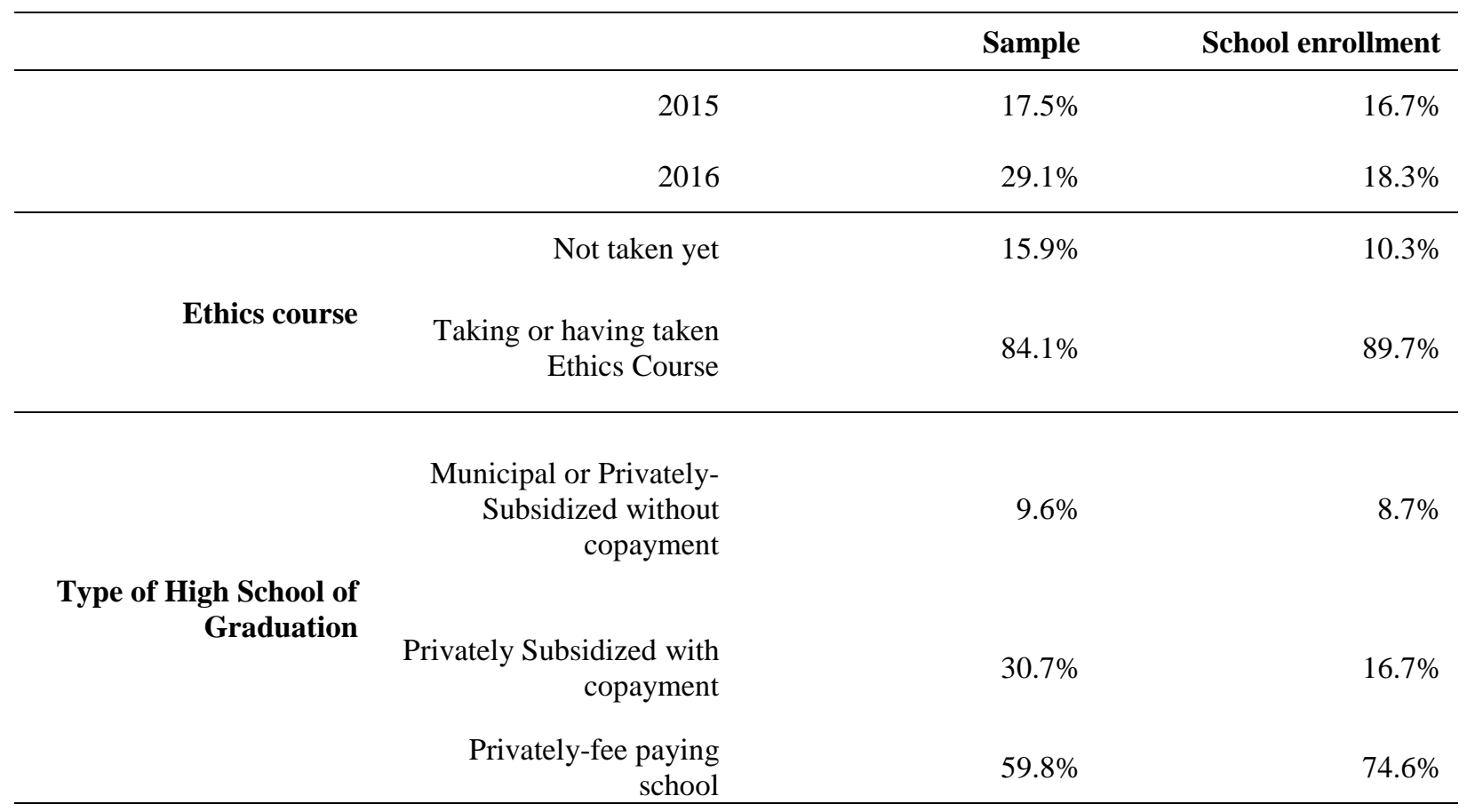

\section{Data Analysis Plan}

Concerning the qualitative data analysis, two reviewers codified the transcripts of the semi-structured interviews in NVivo, and peer-checking was used to guarantee consistency. Concept maps were developed to reduce information and clarify themes, codes and categories. A data matrix was obtained to inform the development of the quantitative instrument. Although we cannot generalize findings, there is evidence from different actors to address internal validity.

Regarding the quantitative data analysis, $18 \%$ of the sample answered the quantitative instrument (379 students). This instrument assessed students' ability to recognize ethical and professional issues to accept personal responsibility, to be aware of ethical codes, and to obtain learning benefits from different ethical teaching activities. The ability to recognize issues was measured in a 7-point scale of 13 items: seven potential ethical issues in engineering education and six in engineering practice (see items of the ethical reasoning scale in Appendix 1). Students were asked to define how ethically wrong were the situations stated in each item from 1 to 7 (1: not wrong at all, 7: completely wrong). We used the exploratory factor analysis (EFA) to reduce responses to all items into one factor. In this case, EFA, as well as other techniques that attempt to identify a latent structure, served our purposes. We obtained a Kaiser Meyer Olkin Coefficient (KMO) of 0.83 , so the data loaded well into one factor ${ }^{18}$. Thus, we developed an ethical reasoning index concerning engineering students' responses, which ranged between between -5.4 and 1.6 (see Figure 2). 
Figure 2: Ethical reasoning index (from -5.4 to 1.6). Lower values indicate that the respondent does not consider a misconduct as unethically wrong as other participants might consider.

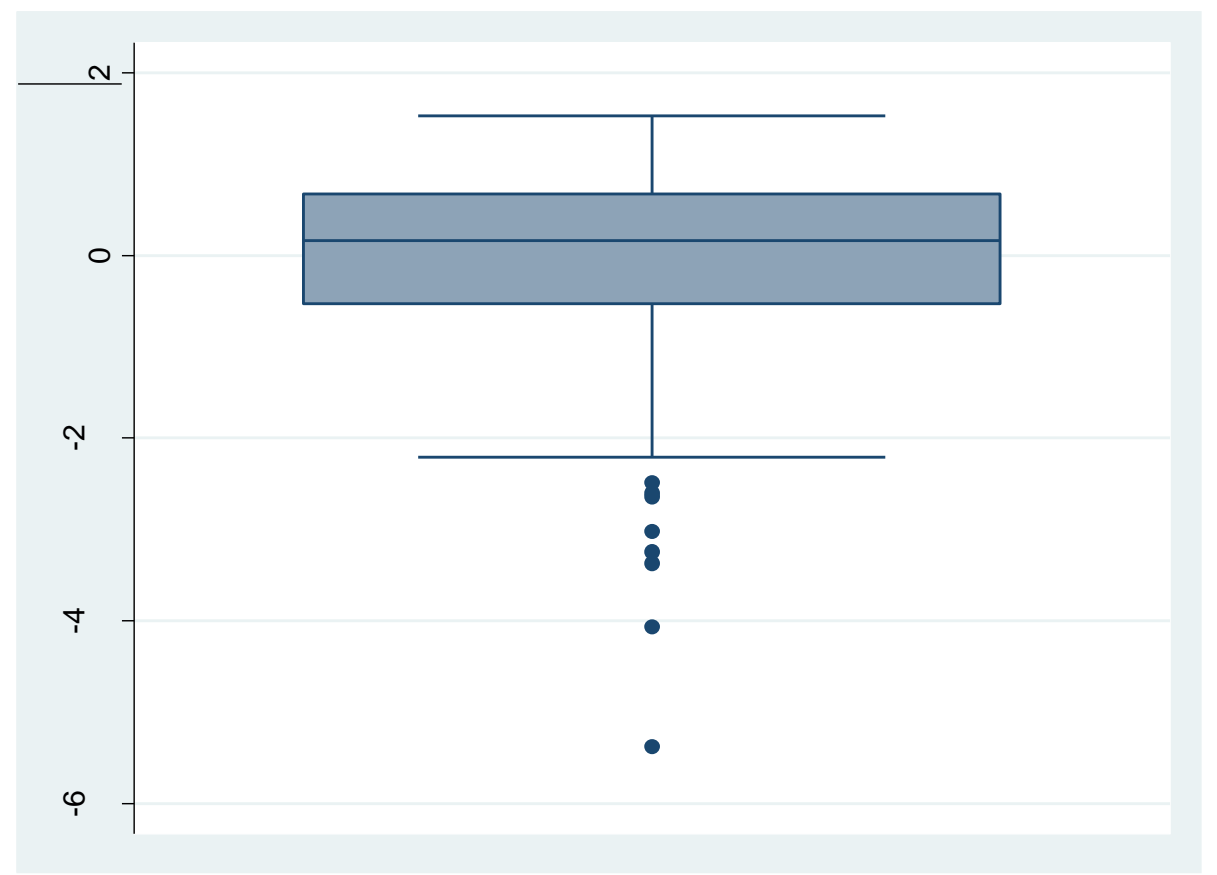

In order to compare the ethical reasoning index among different subgroups, we used the Ordinary Least Squares (OLS) to estimate the significance of strata characteristics over students' ability to recognize issues. We used a regression rather than a Chi-square test to conceive the index as the dependent variable. Linear regression was conducted because the index is a numerical continuous variable. The independent variables where gender, high school of graduation, the admission cohort and having taken the first-year ethics course. We considered the first two variables because female students and those who graduated from private-subsidized and municipal schools are a minority within the student body (see Table 1). Therefore, we wanted to analyze whether there were significant differences in the ethical reasoning of minorities and prevailing students. In case of the other two variables, we wanted to analyze if being freshmen and having taken the ethics course implied any difference in the ability of recognizing ethical issues.

\section{Results}

Interviewees distinguished between formal and informal ethics teaching activities. Formal activities were associated with ethical training embedded in the engineering curriculum. Informal activities were associated with extracurricular experiences that could contribute to students' ethical understanding, such as individual learning and volunteering activities. Regarding learning outcomes, interviewees referred to the ability to recognize professional responsibilities by using ethical codes separately from the individual ethical understanding. From interviewees' perspective, individual ethical reasoning is subject to family and peer influence, besides religion. 
Figures 3 and 4 show concept maps that were used to identify visually main themes, codes, and categories.

Figure 3: Concept Map about Ethics Teaching Activities in the Research Site

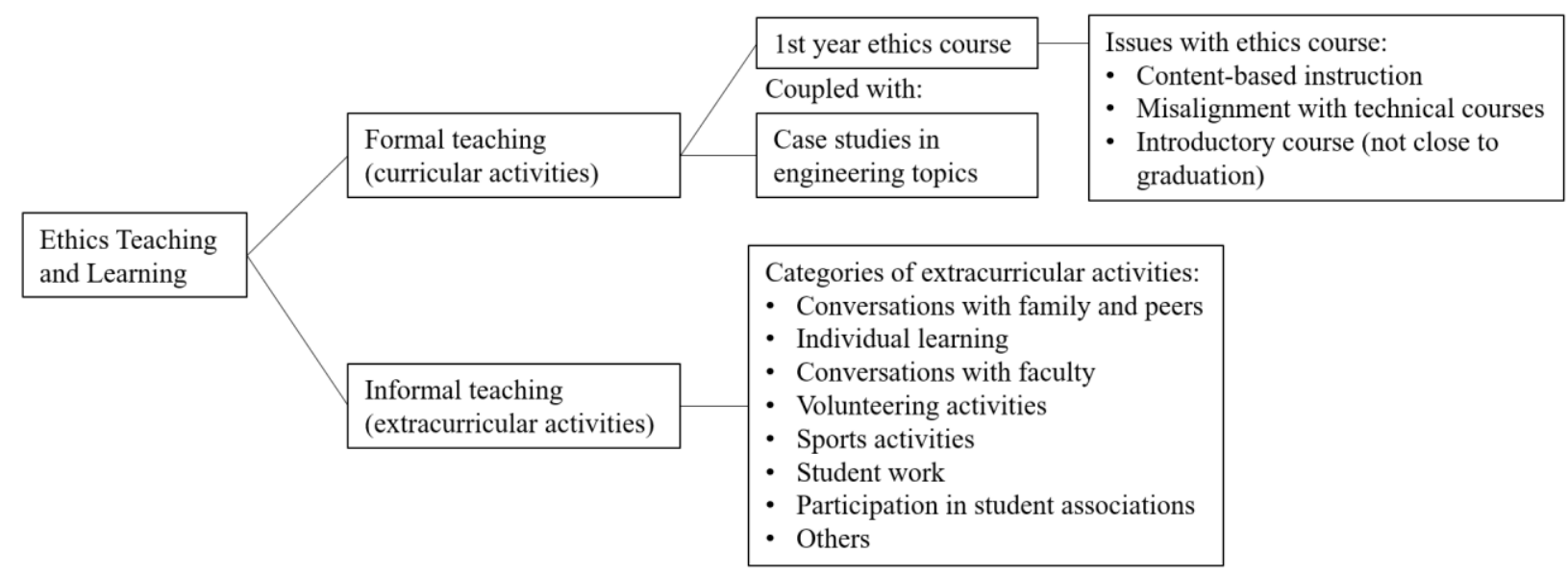

Figure 4: Concept Map about Expected Learning Outcomes of Ethics Teaching

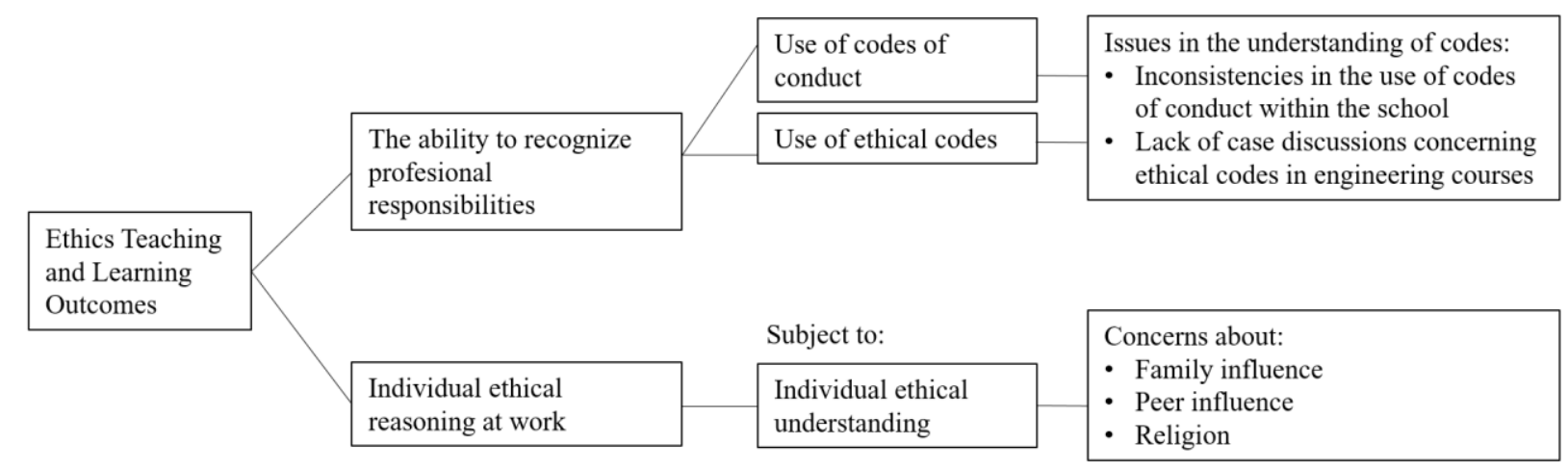

Table 8 shows the qualitative dimensions that were considered in the design of a quantitative questionnaire to assess ethics teaching and learning within the research site. It also shows the explored factors and the questions addressed in the quantitative approach.

Table 8: Qualitative Dimensions used for designing a Quantitative Questionnaire to Assess Different Aspects of Ethics Teaching and Learning within the Research Site

\begin{tabular}{lll}
\hline Qualitative dimensions & Explored factors & $\begin{array}{l}\text { Questions to be addressed in the } \\
\text { quantitative questionnaire }\end{array}$ \\
\hline & $\begin{array}{l}\text { Learning benefits of first year } \\
\text { ethics course }\end{array}$ & $\begin{array}{l}\text { Single-choice question on the importance of } \\
\text { the first-year ethics course for ethical } \\
\text { understanding. }\end{array}$ \\
Formal teaching activities & $\begin{array}{l}\text { Teaching methods perceived as } \\
\text { beneficial }\end{array}$ & $\begin{array}{l}\text { Multiplechoice question on teaching methods } \\
\text { perceived as beneficial for developing ethical } \\
\text { understanding (8 response options). }\end{array}$ \\
\hline
\end{tabular}




\begin{tabular}{lll}
\hline Qualitative dimensions & Explored factors & $\begin{array}{l}\text { Questions to be addressed in the } \\
\text { quantitative questionnaire }\end{array}$ \\
\hline Informal teaching activities & $\begin{array}{l}\text { Extracurricular activities } \\
\text { perceived as beneficial }\end{array}$ & $\begin{array}{l}\text { Multiple-choice question on extracurricular } \\
\text { activities perceived as beneficial for } \\
\text { developing ethical understanding (8 response } \\
\text { options). }\end{array}$ \\
\hline $\begin{array}{l}\text { Moral understanding of } \\
\text { ethical issues during their } \\
\text { engineering studies }\end{array}$ & Student misconducts observed & $\begin{array}{l}\text { Multiple-choice question on misconducts } \\
\text { observed in other students (6 response } \\
\text { options) } \\
\text { Multiple-choice question on misconducts } \\
\text { committed as a student (6 response options). }\end{array}$ \\
\hline Student misconducts committed ef ethics codes & Knowledge of ethics codes & $\begin{array}{l}\text { Single choice question on how familiar you } \\
\text { are with ethical codes (4 response options) }\end{array}$ \\
\hline Individual moral reasoning & $\begin{array}{l}\text { Moral understanding of ethical } \\
\text { issues during their } \\
\text { undergraduate studies } \\
\text { Moral understanding of ethical } \\
\text { issues in the engineering } \\
\text { workplace }\end{array}$ & $\begin{array}{l}\text { 7-point Likert Scale ranging from 1: Not } \\
\text { unethical to 7: Completely unethical. 7 items } \\
\text { over students' issues and 7 items over } \\
\text { workplace issues. }\end{array}$ \\
\hline
\end{tabular}

Table 9 shows that most of the respondents that have taken the first-year ethics course consider that was somewhat important for their current ethical understanding. Nonetheless, more than a third of the respondents consider that it had no importance. Concerning the findings of the qualitative data analysis, this is the only formal training in engineering ethics so far, besides case discussions and ethics lectures that might be included in further courses on engineering topics.

Table 9: Learning benefits perceived from first-year ethics course by questionnaire respondents.

\begin{tabular}{lr}
\hline Response options & $\begin{array}{r}\text { Percentage of } \\
\text { students (out } \\
\text { of 379) }\end{array}$ \\
\hline $\begin{array}{l}\text { The course of ethics was not important for my current } \\
\text { ethical understanding. }\end{array}$ & $35 \%$ \\
$\begin{array}{l}\text { The course of ethics was somewhat important for my } \\
\text { current ethical understanding. }\end{array}$ & $54 \%$ \\
$\begin{array}{l}\text { The course of ethics was crucial for my current ethical } \\
\text { understanding. }\end{array}$ & $11 \%$ \\
\hline
\end{tabular}

Table 10 shows the percentage of respondents that consider specific teaching methodologies as beneficial for developing ethical understanding. The teaching methodology that most respondents mentioned as beneficial was guided discussions in class $(79 \%$ of respondents). The ethics course relies mainly on content-based instruction according to the qualitative information collected in this study. This type of instruction is typically delivered by lectures, which were considered beneficial by $34 \%$ of the respondents.

Table 10: Teaching methodologies perceived as beneficial for developing ethical understanding according to questionnaire respondents. 


\begin{tabular}{lr}
\hline Response options & $\begin{array}{r}\text { Percentage of } \\
\text { students (out } \\
\text { of 379) }\end{array}$ \\
\hline Guided discussion in class & $79 \%$ \\
Guest lecture & $52 \%$ \\
Peer discussion & $50 \%$ \\
Lecture & $34 \%$ \\
Documentary or movie & $23 \%$ \\
Role-play activity & $17 \%$ \\
Gaming-based teaching & $11 \%$ \\
Online material & $9 \%$ \\
Other & $8 \%$ \\
\hline
\end{tabular}

Table 11 shows the percentage of respondents that consider specific extracurricular activities beneficial for developing ethical understanding. The extracurricular activity that most respondents mentioned beneficial was conversations with family and peers ( $85 \%$ of respondents). This response option emerged from qualitative information. Although it does not necessarily depend on the school approach, it reflects the concern on family influence over individual moral reasoning (see Figure 4). Other extracurricular activities that most respondents reported as beneficial were individual learning and volunteering activities (63\% and 52\% respectively).

Table 11: Extracurricular activities perceived as beneficial for developing ethical understanding according to questionnaire respondents.

\begin{tabular}{lr}
\hline Response options & $\begin{array}{r}\text { Percentage of } \\
\text { students (out } \\
\text { of 379) }\end{array}$ \\
\hline Conversations with family and peers & $85 \%$ \\
Individual learning & $63 \%$ \\
Volunteering activities & $52 \%$ \\
Informal conversations with faculty & $47 \%$ \\
Sports activities & $32 \%$ \\
Student work outside the classroom & $22 \%$ \\
Participation in student associations & $10 \%$ \\
Others & $10 \%$ \\
\hline
\end{tabular}

Table 12 shows the percentage of respondents that have observed a specific student misconduct in the last 12 months, besides showing the percentage that recognized having committed a misconduct themselves over the same period of time. The misconducts were defined as respondent options according to the qualitative information collected in group interviews with students. There are student issues such as the free-rider problem that are highly prevalent in the student body, besides the act of signing the attendance list on someone's behalf and cheating in activities within a laboratory module. Furthermore, more than $19 \%$ of the respondents admitted committing those misconducts themselves. 
Table 12: Students' misconducts that respondents declared that they have observed and/or committed in the last 12 months.

\begin{tabular}{lrr}
\hline $\begin{array}{l}\text { Response options (students' } \\
\text { misconducts mentioned in the } \\
\text { qualitative phase of the study) }\end{array}$ & $\begin{array}{r}\text { Percentage of students that } \\
\text { admit having observed the } \\
\text { misconduct (out of 379) }\end{array}$ & $\begin{array}{r}\text { Percentage of students that } \\
\text { admit having committed the } \\
\text { misconduct (out of 379) }\end{array}$ \\
\hline $\begin{array}{l}\text { Free-riding in a teamwork activity } \\
\text { Signing on behalf of someone in an } \\
\text { attendance list }\end{array}$ & $90 \%$ & $24 \%$ \\
Cheating in a lab activity & $70 \%$ & $19 \%$ \\
$\begin{array}{l}\text { Cheating in an exam } \\
\text { Presenting a false certificate for not }\end{array}$ & $65 \%$ & $27 \%$ \\
$\begin{array}{l}\text { attending an exam } \\
\text { Submitting homework that is not their } \\
\text { own }\end{array}$ & $44 \%$ & $8 \%$ \\
\hline
\end{tabular}

Table 13 shows the distribution of respondents according to their knowledge level of ethical codes in engineering. Most of the respondents are aware of the existence of ethical codes, but they neither know their content nor how to apply them when necessary.

Table 13: Respondents' distribution according to how familiar they are with ethical codes and its use in the engineering practice.

\begin{tabular}{lr}
\hline Response options & $\begin{array}{r}\text { Percentage of } \\
\text { students (out of } \\
\text { 379) }\end{array}$ \\
\hline I do not know about the existence of ethical codes. & $11 \%$ \\
$\begin{array}{l}\text { I know about the existence of ethical codes, but I do not know } \\
\text { about their content. }\end{array}$ & $59 \%$ \\
$\begin{array}{l}\text { I know about the content of ethical codes, but I do not know how } \\
\text { these codes are applicable. }\end{array}$ & $5 \%$ \\
$\begin{array}{l}\text { I know about the content of ethical codes, and I know how to } \\
\text { apply them when necessary. }\end{array}$ & $24 \%$ \\
\hline
\end{tabular}

Table 14 shows the results from OLS regression considering the ethical reasoning index as the dependent variable and strata characteristics as the independent variables (see Table 14). Male students showed a significantly lower ethical reasoning index than female students (negative regression coefficient). Additionally, students that graduated from privately-fee paid schools showed a significantly lower ethical reasoning than student that graduated from municipal or privately-subsidized schools without copayment. These type of schools represent Chilean public education, which typically educates students from lower socioeconomic backgrounds ${ }^{19,20}$. Finally, there is a positive effect of taking the first year ethics course on the index. 
Table 14: Results from Ordinary Least Squares Regression considering the ethical reasoning index as the dependent variable and personal characteristics as the independent variable (**** Significance with a confidence level of 99\%; ** Significance with confidence level of 95\%; * Significance with a confidence level of 90\%)
Independent variables according to strata
Coefficient of Regression
(Standard Error)

\begin{tabular}{ll}
\hline $\begin{array}{l}\text { Gender } \\
\text { Being a male student (vs. being a female student) }\end{array}$ & $-0.453(0.097) * * *$ \\
High School of Graduation & \\
$\begin{array}{l}\text { Having attended a privately-subsidized high school with copayment } \\
\text { (vs. municipal or privately subsidized school without copayment) }\end{array}$ & $-0.057(0.165)$ \\
$\begin{array}{l}\text { Having attended a privately-fee paying high school (vs. municipal } \\
\text { or privately subsidized school without copayment) }\end{array}$ & $-0.346(0.169) * *$ \\
Admission cohort & \\
$\begin{array}{l}\text { Freshmen } \\
\text { Having taken the ethics course }\end{array}$ & $0.132(0.165)$ \\
Constant Coefficient & $0.342(0.155)^{* *}$ \\
Adjusted Coefficient of determination $\left(\mathbf{R}^{2}\right)$ & $0.331(0.205)$ \\
\hline
\end{tabular}

\section{Discussion}

From the qualitative information, it is observed that the formal ethical training is disarticulated from extracurricular activities. Regarding the formal training, interviewees alluded exclusively to a first-year course that addresses engineering ethics fundamentals. However, there is no formal training close to the moment of graduation. This confirms difficulties to integrate engineering ethics teaching across the curriculum ${ }^{16}$.

Concerning learning outcomes, interviewees associated the ability to apply ethical codes with ethical training activities such as case discussions. This is aligned to what has been documented in literature ${ }^{9}$. Furthermore, quantitative results revealed that this is an aspect to be improved within the research site. Most respondents were aware of the existence of ethical codes but they did not know how to apply them. Faculty should collaborate with school authorities in order to explore how to integrate the teaching of ethical codes in the core curriculum courses ${ }^{17}$. This also applies to the reinforcement of codes of conduct. Although respondents were able to recognize potential ethical issues in engineering education, there was a high percentage of students' misconducts observed such as free-riding, falsification and plagiarism (see Table 12).

Regarding individual ethical reasoning, engineering students were not necessarily equally capable of recognizing ethical and professional responsibilities. These differences were partially explained by personal characteristics, such as gender and high school of graduation. Therefore, schools of engineering have to offer multiple learning opportunities to ensure that all students increase ethical sensitivity ${ }^{11,13}$. A holistic approach could be used to assess the effects of these opportunities on students' personal standards. 


\section{Conclusions}

There are different aspects to assess the effectiveness of the ethical teaching and learning approach adopted by an engineering school:

- Learning benefits obtained from different curricular and extracurricular activities.

- Learning benefits obtained from different teaching methodologies.

- Students' understanding of codes of conduct and ethical codes.

- Individual ethical reasoning to recognize ethical and professional issues in their current setting and in the future workplace.

The use of qualitative methodology followed by a quantitative approach led to an instrument that assessed different aspects of engineering ethics training. Within the context of a particular engineering school, the questionnaire responses revealed differences among students in learning benefits obtained from the existing formal training (e.g., first year ethics course). It also revealed prevalent problems concerning the understanding of professional ethics (e.g., lack of ethical code awareness) and students' conduct (e.g., free-riding in teamwork activities).

The ethical reasoning scale showed differences in the understanding of different subgroups. Moreover, the prevailing student type at the research site is the one that experienced more difficulties to recognize how ethically wrong a potential issue was. By prevailing students, we are referring to a male youngster who graduated from a privately-fee paid school (see Table 8). Thus, future work might imply exploring deeply the dominant culture of the research site in order to understand how personal characteristics shape ethical decision-making.

Towards continuous improvement, most respondents revealed that a first-year course could be somewhat important for developing ethical understanding among students. Then, an ethics course is not enough for ensuring that all students are prepared to face diverse ethical issues in the workplace. Nonetheless, respondents identified teaching methodologies and extracurricular activities that were perceived as beneficial among students, such as guided discussions in class and informal conversations with peers. Therefore, the assessment approach adopted in this study could be implemented in other institutions to identify strategies for integrating ethics teaching across the curriculum.

\section{References}

1. Fleddermann, C., 2004. Engineering Ethics. 2da ed. Upper Saddle River, NJ: Pearson Prentice Hall.

2. Jonassen, D., Shen, Marra, Cho, Lo \& Lohani. 2009. Engaging and Supporting Problem Solving in Engineering Ethics. Journal of Engineering Education, 98(3), pp. 235-254.

3. Lattuca, L. R., Terenzini, P.T., \& Volkein, J. F. (2006) Engineering Change: A Study of the Impact of EC2000. ABET: Baltimore

4. ABET. 2016-2017 Criteria from Accrediting Engineering Programs-Proposed Changes. Retrieved from: http://www.abet.org/wp-content/uploads/2015/11/Proposed-Revisions-to-EAC-Criteria-3-and-5.pdf 
5. Slaton, A. E. \& Riley, D. M. 2015. The Wrong Solutions for STEM Education. Inside Higher Ed. Retrieved from: https://www.insidehighered.com/views/2015/07/08/essay-criticizes-proposed-changes-engineeringaccreditation-standards

6. Shuman, L. et al. 2004. Can Our Students Recognize and Resolve Ethical Dilemmas? Pittsburgh, s.n., pp. $1-15$.

7. Self, D. \& Ellison, E., 1998. Teaching Engineering Ethics: Assessment of Its Influence on Moral Reasoning Skills. Journal of Engineering Education, 87(1), pp. 29-34.

8. Finelli, Holsappel, Ra, Bielby, Burt, Carpenter, Harding \& Sutkus. 2012. An Assessment of Engineering Students' Curricular and Co-Curricular Experiences in their Ethical Development. Journal of Engineering Education, 101(3), pp. 469-494.

9. Colby, A. \& Sullivan, W., 2008. Ethics Teaching in Undergraduate Engineering Education. Journal of Engineering Education, 97(3), pp. 327-338.

10. Little, P., Hink, R. \& Barney, D., 2007. Living up to the code: Engineering as political judgment, Claremont, CA: s.n.

11. Davis, M., 1999. Ethics and the University. Londres: Routledge.

12. Devon, R., 1999. Towards a Social Ethics of Engineering: The Norms of Engagement. Journal of Engineering Education, 88(1), pp. 87-92.

13. Herkert, J. 2005. Ways of Thinking about Teaching Ethical Problem Solving: Microethics and Macroethics in Engineering. Science and Engineering Ethics. 11, pp. 373-385.

14. May, D. \& Luth, M. T. 2013. The Effectiveness of Ethics Education: A Quasi-Experimental Field Study. Science and Engineering Ethics. 19, 545-568.

15. Basart, J. M. \& Serra, M. 2013. Engineering Ethics Beyond Engineers' Ethics. Science and Engineering Ethics. 19, pp. 179-187.

16. Hamad, J. A., Hasanain, M., Abdulwahed, M., \& Al-Ammari, R. (2013). Ethics in Engineering Education A Literature Review. Frontiers in Education Conference, 2013 IEEE, 1554-1560.

17. Li, J. \& Fu, S. (2012). A Systematic Approach to Engineering Ethics Education. Science and Engineering Ethics. 18, pp. 339-349.

18. Beavers, A. S., Lounsbury, J. W., Richards, J. K., Huck, S. W., Skolits, G. J., \& Esquivel, S. L. (2013). Educational Research, 18(6).

19. Koljatic, Mladen, and Monica Silva. 2013. "Opening a side gate: engaging the excluded in Chilean Higher Education through test-blind admission." Studies in Higher Education 38 (10): 1427-1441. doi: 10.1080/03075079.2011.623299.

20. Koljatic, Mladen, Mónica Silva, and Rodrigo Cofré. 2013. "Achievement versus aptitude in college admissions: A cautionary note based on evidence from Chile." International Journal of Educational Development 33 (1): 106-115. doi: 10.1016/j.ijedudev.2012.03.001. 


\section{Appendix 1. Ethical Reasoning scale}

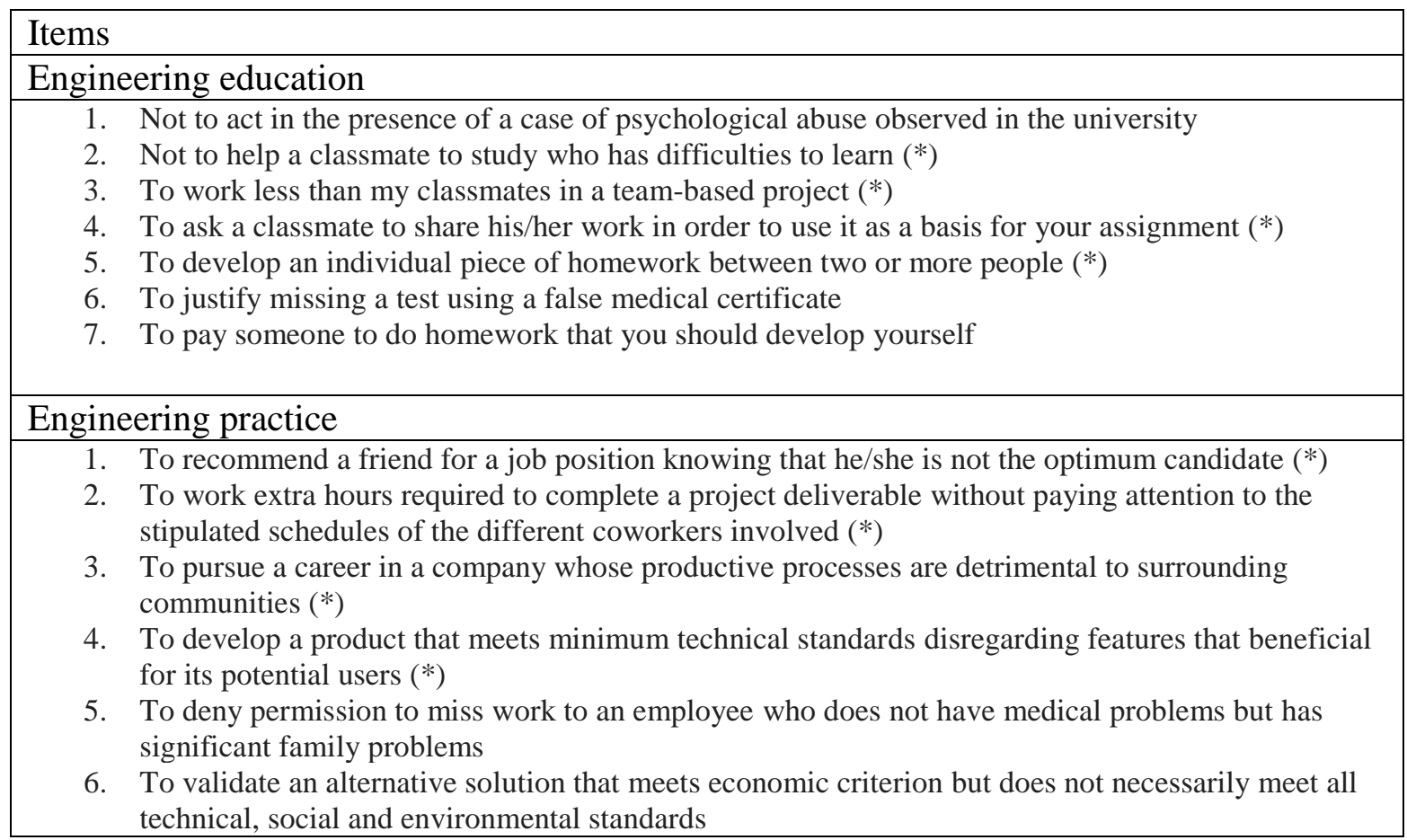

Note:

(*) These were the most discriminating items. 